\title{
G Beta-Gamma
}

National Cancer Institute

\section{Source}

National Cancer Institute. G Beta-Gamma. NCI Thesaurus. Code C19274.

G beta-gamma dimers associate with the alpha subunit to comprise heterotrimeric $\mathrm{G}$ proteins. This dimer stimulates various, and sometimes opposing, cell signaling events in response to ligation of a $\mathrm{G}$ protein coupled receptor, such as the beta-adrenergic, adenosine, dopamine, LTB4, and PGE2 receptors, among many others. 